\title{
Otolith Sr:Ca ratio and morphometry as indicators of habitat of a euryhaline species: The case of the silverside Odontesthes bonariensis
}

\section{La relación Sr:Ca y la morfometría del otolito como indicadores de hábitat de una especie eurihalina: El caso del pejerrey Odontesthes bonariensis}

\author{
Esteban Avigliano $^{1 *}$, Paola Villatarco ${ }^{2}$, Alejandra V Volpedo ${ }^{1}$ \\ ${ }^{1}$ Instituto de Investigaciones en Producción Animal-Concejo Nacional de Investigaciones Científicas y \\ Técnicas-Universidad de Buenos Aires (INPA-CONICET-UBA), Av. Chorroarín 280 (C1427CWO), \\ Buenos Aires, Argentina \\ ${ }^{2}$ Centro Austral de Investigaciones Científicas-Concejo Nacional de Investigaciones Científicas y Técnicas \\ (CADIC-CONICET), Bernardo Houssay 200 (V9410CAB), Ushuaia, Argentina
}

*Corresponding author. E-mail: estebanavigliano@yahoo.com.ar

\begin{abstract}
The silverside Odontesthes bonariensis is a euryhaline species native of South America and represents a very important fishing resource for the Plata Basin (Argentina and Uruguay). This study compares the Sr:Ca ratio of water as well as the Sr:Ca ratio and morphometry of the sagittal otolith of the silverside present in different environments (one salt lake, two freshwater dams, one lagoon, and one estuary) in order to evaluate the use of these variables as markers of habitat. The pattern of the Sr:Ca ratio in the water agrees with the one found in the otoliths, showing a positive relationship with the conductivity of the water. Univariate and multivariate analyses of variance indicated significant differences $(P<0.05)$ among the localities studied for the morphometric indices. The discriminant function analysis provided a high percentage of correctly classified individuals for the saltwater environment $(100 \%)$ and the lentic water bodies and estuary $(60-80 \%)$, circularity and form factor being the most relevant morphometric variables. These results indicate that the $\mathrm{Sr}$ :Ca ratio and otolith morphometry are good markers of habitat for this important resource.
\end{abstract}

Key words: morphometry, Sr:Ca, otolith, Odontesthes bonariensis, Argentina.

RESUMEN. El pejerrey Odontesthes bonariensis es una especie eurihalina nativa de Sudamérica y representa un importante recurso pesquero para la cuenca del Plata (Argentina y Uruguay). En este estudio se comparó la relación Sr:Ca del agua y la relación Sr.:Ca y morfometría de los otolitos sagittae de pejerreyes presentes en diferentes ambientes (un lago de agua salada, dos embalses de agua dulce, una laguna y un estuario) con el objetivo de evaluar el uso de estas variables como marcadores de hábitat. El patrón de la relación Sr:Ca del agua concuerda con la hallada en los otolitos, mostrando una relación positiva con la conductividad del agua. Los análisis univariados y multivariados indicaron diferencias $(P<0.05)$ entre las localidades estudiadas para los índices morfométricos. El análisis discriminante mostró un elevado porcentaje de individuos correctamente clasificados para el ambiente de agua salada (100\%), los cuerpos de agua lenticos y el estuario (60-80\%), siendo la circularidad y el factor de forma los índices morfométricos de mayor relevancia para esta clasificación. Estos resultados indican que la relación Sr:Ca y la morfometría del otolito son buenos marcadores de hábitat para este importante recurso.

Palabras clave: morfometría, Sr:Ca, otolito, Odontesthes bonariensis, Argentina.

\section{INTRODUCTION}

The Argentinian silverside, Odontesthes bonariensis (Valenciennes 1833), is one of the most important fishery resources in estuaries and rivers of southwestern South America. This species inhabits diverse habitats such as dams, lakes, rivers, lagoons, and estuaries in Argentina, Uruguay, Brazil, and Chile, and has been introduced into other South American countries (e.g., Bolivia and Peru) and other continents (e.g., Europe and Asia) (Chiba et al. 1989, Gandolfi et al. 1991, Brian and Dyer 2006, Avigliano and Volpedo 2013a). In Argentina, Brazil, and Uruguay it is found in the Plata Basin and in lentic water bodies such as dams, lakes, and lagoons, both artificial and natural (Brian and Dyer 2006, Tombari and Volpedo 2008, Avigliano and Volpedo 2013a). In general, during the larval and juvenile stages, this species

\section{INTRODUCCIÓN}

El pejerrey argentino, Odontesthes bonariensis (Valenciennes 1833), es uno de los recursos pesqueros de mayor importancia en estuarios y ríos de la región sudoccidental de Sudamérica. Esta especie está distribuida en diferentes ambientes como embalses, lagos, ríos, albuferas y estuarios en Argentina, Uruguay, Brasil y Chile, y ha sido introducida en otros países de Sudamérica (e.g., Bolivia y Perú) y en otros continentes (e.g., Europa y Asia) (Chiba et al. 1989, Gandolfi et al. 1991, Brian y Dyer 2006, Avigliano y Volpedo 2013a). En Argentina, Brasil y Uruguay se distribuye en la cuenca del Plata y en cuerpos de agua lénticos como embalses, lagos y lagunas, tanto artificiales como naturales (Brian y Dyer 2006, Tombari y Volpedo 2008, Avigliano y Volpedo 2013a). En líneas generales, 
feeds primarily on plankton, whereas during the adult stage, it also ingests other organisms such as gastropod molluses and crustaceans (Escalante and Grosman 2001); however, in lotic water bodies where plankton is relatively scarce, such as the Plata River estuary, the silverside's diet is mainly based on molluscs and fish (Escalante and Grosman 2001). This species presents temperature-dependent sex determination. Spawning generally occurs twice a year, from March to April and from August to November (Barco 1986). Sexual maturity is attained between the first and second year of life (total length of $\sim 140 \mathrm{~mm}$ ), depending on the region (Barco 1986).

The silverside is the second most important freshwater fishery resource in Argentina and Uruguay, and a large part of the production is exported to Europe (the Netherlands, Italy, and Ukraine), Russia, and the United States (MINAGRI 2014). The volume of exported silverside derives exclusively from the lower section of the Plata Basin (Plata River, Uruguay River, and Paraná River) and has increased in recent years, from $64 \mathrm{t}$ in 2007 to $551 \mathrm{t}$ in 2012, with an export peak (724 t) in 2008 (MINAGRI 2014).

Avigliano et al. (2014) suggested the possible existence of two fish stocks with a high degree of connectivity in the lower section of the Plata Basin, one corresponding to the Uruguay River and Paraná Delta and the other to the Plata estuary; however, historical catch data and data on the status of these stocks are lacking. Information is also lacking on the connectivity between these populations and those from other basins in the region, such as the Negro River (Uruguay) or the Salado River (Argentina), among others. In particular, the Salado River basin is connected to several lentic water bodies of the Pampean Plain (e.g., the lagoons Chascomús, Barranca, Adela, Chis Chis, El Burro) where the species is caught for subsistence, recreational, and, to a lesser extent, commercial purposes. Despite the importance of this resource, specific management measures have not been devised for the silverside in the Plata Basin. Identifying the fish stocks is therefore important to be able to generate stockspecific tools for the sustainable management of the silverside populations.

Among the most commonly used approaches for identifying stocks are capture-recapture procedures, size structure analysis, genetic identification, and otolith morphometry and microchemistry analysis (e.g., Park and Moran 1994). The otoliths of teleost fish, located in the vestibular system, are complex polycrystalline structures composed mainly of calcium carbonate and small amounts of other minerals (trace elements) immersed in an organic matrix (Campana 1999). In certain species, the concentration of some of these elements, like strontium, barium, zinc, and magnesium, among others, is related to the their concentration in water (Campana 1999, Sturrock et al. 2012, Avigliano 2014). These characteristics, coupled with the fact that they are inert and acellular metabolic structures that constantly incorporate chemical elements from water, make otoliths a useful tool for fish stock assessments and life history studies (Campana 1999; durante el estadio larval y juvenil, esta especie se alimenta principalmente de plancton, mientras que en el estadio adulto, incorpora además otros organismos como moluscos gasterópodos y crustáceos (Escalante y Grosman 2001). Sin embargo, en cuerpos de agua lóticos donde el plancton es relativamente escaso, como en el estuario del Río de la Plata, la dieta del pejerrey está basada principalmente en moluscos y peces (Escalante y Grosman 2001). La diferenciación sexual del pejerrey es termo-dependiente. Normalmente existen dos periodos de desove, uno de marzo a abril y el otro comprendido de agosto a noviembre (Barco 1986). Esta especie alcanza la madurez sexual entre el primer y segundo año de vida (talla total de $\sim 140 \mathrm{~mm}$ ), según las diferentes regiones (Barco 1986).

El pejerrey representa el segundo recurso pesquero de agua dulce más importante de Argentina y Uruguay, y una gran proporción de la producción es exportada a Europa (Italia, Países Bajos y Ucrania), Rusia y los Estados Unidos de América (MINAGRI 2014). El volumen de pejerrey exportado proviene exclusivamente de la cuenca baja del Plata (estuario del Río de la Plata, río Uruguay y río Paraná) y se ha incrementado en los últimos años, pasando de $64 \mathrm{t}$ en 2007 a 551 t en 2012, con un pico de exportación de 724 t en 2008 (MINAGRI 2014).

En la cuenca baja del Plata se ha sugerido la existencia de dos poblaciones pesqueras con alto grado de conectividad, una correspondiente al río Uruguay y delta del Paraná y la otra al estuario del Río de la Plata (Avigliano et al. 2014). Sin embargo, no hay datos sobre el estado de estas poblaciones ni registros históricos de capturas. Además, no hay información sobre la conectividad de estas poblaciones con las de otras cuencas de la región, como el río Negro (Uruguay) o el río Salado (Argentina), entre otras. Particularmente, la cuenca del Salado está conectada con una gran cantidad de cuerpos de agua lénticos de la llanura pampeana (e.g., lagunas Chascomús, Barranca, Adela, Chis Chis, El Burro) donde la especie es capturada a nivel de subsistencia, pesca deportiva $y$, en menor medida, comercial. A pesar de la importancia que reviste este recurso, no existen normativas de manejo específicas para el pejerrey en la cuenca del Plata. Identificar las poblaciones pesqueras es de suma importancia para generar herramientas específicas de cada una que contribuyan al manejo sustentable de las poblaciones de pejerrey.

Entre las herramientas más utilizadas para la identificación de las poblaciones pesqueras están los métodos de captura-recaptura, el análisis de estructura de tallas, la identificación genética y el análisis de la morfometría y microquímica de los otolitos (e.g., Park y Moran 1994). Los otolitos de los peces teleósteos, alojados en el aparato vestibular, son complejos cuerpos policristalinos compuestos principalmente por carbonato de calcio y pequeñas cantidades de otros minerales (elementos traza) inmersos dentro de una matriz orgánica (Campana 1999). En determinadas especies, la concentración de algunos de estos elementos, tales como el estroncio, bario, zinc y magnesio, está 
Avigliano and Volpedo 2013b; Avigliano et al. 2014, 2015a, 2015b, 2015c).

In view of the positive relationship that exists between salinity and the strontium:calcium $(\mathrm{Sr}: \mathrm{Ca})$ ratio in water and some fish otoliths (Secor et al. 1995, Zlokovitz et al. 2003, Kraus and Secor 2004, Schuchert et al. 2010, Tabouret et al. 2010, Avigliano et al. 2014), studies relating water parameters ( $\mathrm{Sr}: \mathrm{Ca}$ and salinity) and the otolith $\mathrm{Sr}: \mathrm{Ca}$ ratio have been able to identify fish stocks and migratory routes (e.g., Secor et al. 1995; Zlokovitz et al. 2003; Tabouret et al. 2010; Avigliano et al. 2015b, 2015c). Otolith morphometrics are also used to identify fish stocks (e.g., Longmore et al. 2010, Cañás et al. 2012, Avigliano et al. 2014, Keating et al. 2014, Vieira et al. 2014). The morphometric analysis of otoliths permits a quantitative description of the shape and contour that can be statistically compared (Lestrel 1997). Some of the most commonly used shape indices are circularity, rectangularity, ellipticity, form factor, and sulcus area/otolith area (e.g., Volpedo et al. 2008, Longmore et al. 2010, Cañás et al. 2012, Tuset et al. 2013, Avigliano et al. 2014). In recent studies, both methods have been used (e.g., Longmore et al. 2010, Avigliano et al. 2014).

The objective of this study was to compare the Sr:Ca ratio and morphometry of the sagittal otolith of a euryhaline species, the silverside $O$. bonariensis, from different environments in Argentina (dam, lake, lagoon, and estuary) in order to evaluate the use of these variables as markers of habitat. This information is important for fish stock identification and interconnectivity studies and the development of management policies.

\section{MATERIALS AND METHODS}

\section{Study area}

Water bodies located in three different regions of Argentina were studied (fig. 1). In the northwest, samples were collected from two artificial dams: Los Alisos $\left(24^{\circ} 11^{\prime} \mathrm{S}-65^{\circ} 18^{\prime} \mathrm{W}\right)$ and Cabra Corral $\left(25^{\circ} 27^{\prime} \mathrm{S}-65^{\circ} 27^{\prime} \mathrm{W}\right)$. Los Alisos Dam, located $1260 \mathrm{~m}$ above sea level, has an electrical conductivity of $<250 \mu \mathrm{S} \mathrm{cm}^{-1}$ and maximum depth of $22 \mathrm{~m}$. Cabra Corral Dam, located $1100 \mathrm{~m}$ above sea level, along the Juramento River, has a mean electrical conductivity of $421 \mu \mathrm{S} \mathrm{cm}^{-1}$ and maximum depth of $90 \mathrm{~m}$ (Muñoz et al. 2005). The dams are not interconnected and the region has a subtropical semi-arid climate.

In the Pampean Plain (humid pampa), samples were collected from the Plata River $\left(35^{\circ} 3^{\prime} 5.09^{\prime \prime} \mathrm{S}, 57^{\circ} 2^{\prime} 47.79^{\prime \prime} \mathrm{W}\right)$ and Chascomús Lagoon $\left(35^{\circ} 34^{\prime} 00^{\prime \prime} \mathrm{S}, 58^{\circ} 01^{\prime} 00^{\prime \prime} \mathrm{W}\right)$. The Plata River is a wide estuary that receives the waters from the Plata Basin and flows into the Atlantic Ocean. It has a mean depth of between 5 and $25 \mathrm{~m}$ (Guerrero et al. 2010) and the electrical conductivity ranges from 67 to $30,300 \mu \mathrm{S} \mathrm{cm}^{-1}$ (Avigliano and Volpedo 2013b). Chascomús Lagoon is located $10 \mathrm{~m}$ above sea level and forms part of the lower relacionada con la concentración de los mismos en el agua (Campana 1999, Sturrock et al. 2012, Avigliano 2014). Estas características, sumadas al hecho de que son estructuras metabólicamente inertes y acelulares que incorporan elementos químicos en forma constante del agua, hacen que los otolitos sean una herramienta muy útil para estudios de poblaciones pesqueras e historia de vida de los peces (Campana 1999; Avigliano y Volpedo 2013b; Avigliano et al. 2014, 2015a, 2015b, 2015c).

Debido a que existe una relación positiva entre la salinidad y la relación estroncio:calcio ( $\mathrm{Sr}: \mathrm{Ca})$ del agua y del otolito de algunas especies de peces (Secor et al. 1995, Zlokovitz et al. 2003, Kraus y Secor 2004, Schuchert et al. 2010, Tabouret et al. 2010, Avigliano et al. 2014), se han desarrollado estudios que permiten relacionar parámetros del agua (Sr:Ca y salinidad) con la relación $\mathrm{Sr}: \mathrm{Ca}$ de los otolitos para identificar rutas migratorias y poblaciones pesqueras (e.g., Secor et al. 1995; Zlokovitz et al. 2003; Tabouret et al. 2010; Avigliano et al. 2015b, 2015c). Otra herramienta ampliamente utilizada para la determinación de poblaciones pesqueras es la morfometría del otolito (e.g., Longmore et al. 2010, Cañás et al. 2012, Avigliano et al. 2014, Keating et al. 2014, Vieira et al. 2014). El análisis de la morfometría de los otolitos permite generar una descripción cuantitativa de la forma y el contorno que puede compararse estadísticamente (Lestrel 1997). Entre los índices morfométricos más utilizados están la circularidad, rectangularidad, elipticidad, factor de forma y área del sulcus/área del otolito (e.g., Volpedo et al. 2008, Longmore et al. 2010, Cañás et al. 2012, Tuset et al. 2013, Avigliano et al. 2014). De hecho, ambas metodologías se han usado conjuntamente en estudios recientes (e.g., Longmore et al. 2010, Avigliano et al. 2014).

En este contexto, se comparó la relación Sr:Ca y morfometría del otolito sagitta de una especie eurihalina, el pejerrey $O$. bonariensis, entre diferentes ambientes de Argentina (diques, lagos, lagunas y estuarios) con el fin de evaluar el uso de estas variables como marcadores de hábitat. Esta información es de gran importancia para estudios de identificación de poblaciones pesqueras e interconectividad y para el desarrollo de políticas de manejo.

\section{MATERIALES Y MÉTODOS}

\section{Área de estudio}

Se estudiaron cuerpos de agua ubicados en tres diferentes regiones de Argentina (fig. 1). En el noroeste las muestras fueron colectadas en los embalses artificiales Los Alisos $\left(24^{\circ} 11^{\prime} \mathrm{S}, 65^{\circ} 18^{\prime} \mathrm{W}\right)$ y Cabra Corral $\left(25^{\circ} 27^{\prime} \mathrm{S}, 65^{\circ} 27^{\prime} \mathrm{W}\right)$. El embalse Los Alisos está ubicado a $1260 \mathrm{~m}$ sobre el nivel del mar, y tiene una conductividad eléctrica menor que $250 \mu \mathrm{S} \mathrm{cm}^{-1}$ y profundidad máxima de $22 \mathrm{~m}$. El embalse Cabra Corral está ubicado a $1100 \mathrm{~m}$ sobre el nivel del mar, en el Río Juramento, y tiene conductividad eléctrica media de 


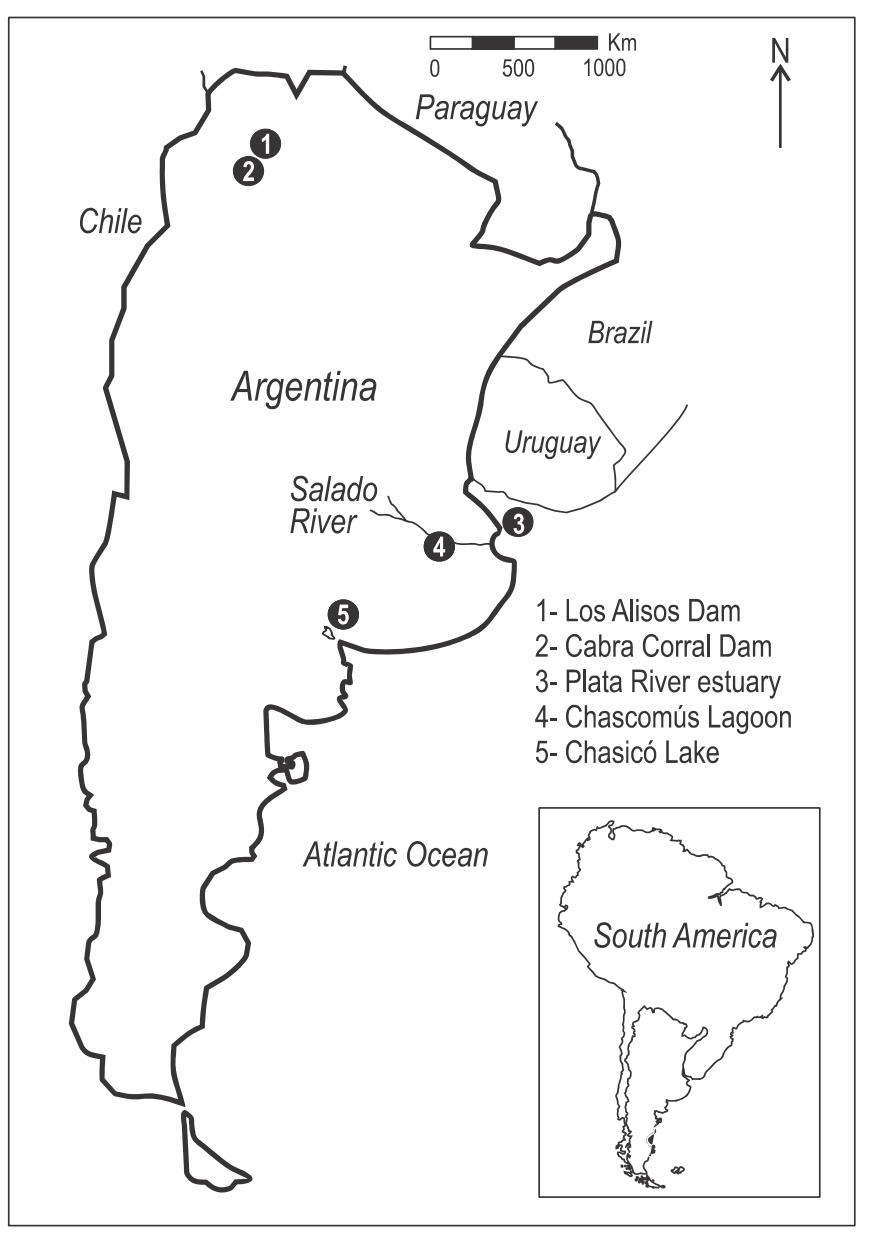

Figure 1. Study area. The numbered circles indicate the water and silverside (Odontesthes bonariensis) collection sites.

Figura 1. Área de estudio. Los puntos numerados indican los sitios de muestreo de agua y captura de pejerrey (Odontesthes bonariensis).

basin of the Salado River. It has a maximum depth of $3.4 \mathrm{~m}$ and mean conductivity is $2200 \mu \mathrm{S} \mathrm{cm}^{-1}$ (Llames et al. 2009). The region has a warm temperate climate and the hydrological regime alternates between flood and dry periods (Vervoorst 1967). Flooding produces channels that connect Chascomús Lagoon with the Plata estuary via the Salado River.

Chasicó Lake (38 $\left.36^{\prime} 39.41^{\prime \prime} \mathrm{S}, 63^{\circ} 4^{\prime} 48.68^{\prime \prime} \mathrm{W}\right)$, located $-20 \mathrm{~m}$ above sea level in a transition area between the Pampean and Patagonian regions, is independent from the other systems studied. It has a maximum depth of $16 \mathrm{~m}$ and the electrical conductivity is high $\left(38.800 \mu \mathrm{S} \mathrm{cm}^{-1}\right)$ (Avigliano et al. 2012).

\section{Sample collection}

Water and fish samples were collected simultaneously between August and September 2011 from the two dams
$421 \mu \mathrm{S} \mathrm{cm}^{-1}$ y profundidad máxima de $90 \mathrm{~m}$ (Muñoz et al. 2005). Estos diques no están conectados entre sí, y el clima de la región es del tipo subtropical semiárido.

En la llanura pampeana (pampa húmeda) las muestras se recolectaron en el estuario del Río de la Plata $\left(35^{\circ} 3^{\prime} 5.09^{\prime \prime} \mathrm{S}\right.$, $\left.57^{\circ} 2^{\prime} 47.79^{\prime \prime} \mathrm{W}\right)$ y la laguna Chascomús $\left(35^{\circ} 34^{\prime} 00^{\prime \prime} \mathrm{S}\right.$, $\left.58^{\circ} 01^{\prime} 00^{\prime \prime} \mathrm{W}\right)$. El estuario del Río de la Plata recibe las aguas de la cuenca del Plata y descarga sobre el océano Atlántico. El intervalo de conductividad eléctrica es de 67 a $30,300 \mu \mathrm{S} \mathrm{cm}^{-1}$ (Avigliano y Volpedo 2013b) y la profundidad media se encuentra entre 5 y $25 \mathrm{~m}$ (Guerrero et al. 2010). La laguna Chascomús está ubicada a $10 \mathrm{~m}$ sobre el nivel del mar y forma parte de la cuenca inferior del río Salado. $\mathrm{La}$ conductividad media es de $2200 \mu \mathrm{S} \mathrm{cm}^{-1}$ y la profundidad máxima es de $3.4 \mathrm{~m}$ (Llames et al. 2009). El clima de la región es templado-cálido y se caracteriza por un régimen hidrológico que alterna entre períodos de inundaciones y sequías (Vervoorst 1967). Estas inundaciones producen canales que conectan la laguna de Chascomús con el estuario del Río de la Plata a través del río Salado.

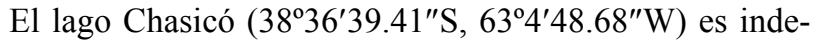
pendiente del resto de los sistemas estudiados y está ubicado a -20 m sobre el nivel del mar en una zona de transición entre la región Pampeana y la Patagonia. Posee agua con elevada conductividad $\left(38.800 \mu \mathrm{S} \mathrm{cm}^{-1}\right)$ y profundidad máxima de $16 \mathrm{~m}$ (Avigliano et al. 2012).

\section{Recolecta de muestras}

Las muestras de agua y peces fueron recolectadas simultáneamente entre agosto y septiembre de 2011 en los embalses Los Alisos y Cabra Corral, el estuario del Rio de la Plata, la laguna Chascomús y el lago Chasicó. Las muestras de agua fueron recolectadas manualmente por triplicado a $0.5 \mathrm{~m}$ de profundidad con botellas de polietileno previamente lavadas tres veces con agua destilada y agua del sitio de muestreo. Estas muestras fueron acidificadas al $0.2 \%(\mathrm{v} / \mathrm{v})(\mathrm{pH}<2)$ con ácido nítrico y trasladadas al laboratorio en oscuridad a $4{ }^{\circ} \mathrm{C}$. Posteriormente fueron filtradas al vacío con filtros Whatman $\mathrm{GF} / \mathrm{F}$ de $0.45 \mu \mathrm{m}$. Las muestras se mantuvieron a $4^{\circ} \mathrm{C}$ hasta su análisis. Los métodos de recolecta, preservación, preparación y análisis fueron realizados acorde a los métodos estandarizados (APHA 1995).

Los ejemplares de $O$. bonariensis fueron capturados con redes de tres mallas de multifilamento (malla interna de $3 \times 3 \mathrm{~cm}$, mallas externas de $10 \times 10 \mathrm{~cm}$ ) y con anzuelo. Estos peces fueron trasladados al laboratorio a $4{ }^{\circ} \mathrm{C}$ donde se registró la talla y se extrajeron los otolitos sagittae. En todos los casos, se trabajó con ejemplares adultos y sexualmente maduros (talla de madurez sexual aproximada $=140 \mathrm{~mm}$, Barco 1986). La estadística descriptiva referente a la talla y el número de individuos utilizados por sitio de estudio se muestran en la tabla 1. 
(Los Alisos and Cabra Corral), Plata estuary, Chascomús Lagoon, and Chasicó Lake. Triplicate water samples were collected manually at $0.5 \mathrm{~m}$ depth using polyethylene bottles previously washed three times with distilled water and water from the sampling site. The samples were acidified to $0.2 \%$ $(\mathrm{v} / \mathrm{v})(\mathrm{pH}<2)$ using nitric acid and transported in darkness at $4{ }^{\circ} \mathrm{C}$ to the laboratory. They were then vacuum-filtered through $0.45-\mu \mathrm{m}$ Whatman $\mathrm{GF} / \mathrm{F}$ filters. The samples were kept at $4{ }^{\circ} \mathrm{C}$ until analysis. Sample collection, preservation, preparation, and analysis were conducted according to standardized methods (APHA 1995).

Specimens of $O$. bonariensis were caught using multifilament three-layer nets (inner mesh, $3 \times 3 \mathrm{~cm}$; external meshes, $10 \times 10 \mathrm{~cm})$ and with hooks. They were transported to the laboratory at $4{ }^{\circ} \mathrm{C}$ where the size was measured and the sagittal otoliths were extracted. In all cases, the specimens were sexually mature adults (size at sexual maturity $=\sim 140 \mathrm{~mm}$, Barco 1986). Mean size, size range, and number of individuals used per site is shown in table 1 .

\section{Determination of water and otolith $\mathrm{Sr}$ and $\mathrm{Ca}$}

The concentration of $\mathrm{Ca}$ in water was determined (in triplicate) by volumetic titrations with ethylenediaminetetraacetic acid (EDTA) (APHA 1995). The concentration of $\mathrm{Sr}$ in water was determined (in triplicate) using an inductively coupled plasma optical emission spectrometer (ICP-OES, PerkinElmer Optima 2000 DV, Überlingen, Germany), equipped with a cross-flow nebulizer, Scott chamber, and quartz torch (method 200.7, EPA 1994). We used an attenuated radial view axis (detection limit $=12 \mu \mathrm{g} \mathrm{L}^{-1}$ ). The samples were introduced into the equipment with a PerkinElmer AS-90 Plus autosampler. External calibrations were performed in all cases using PerkinElmer Pure Quality Control Standard 21 (QCS 21, USA). Every 10 samples, a blank and a sample of known concentration prepared from the QCS 21 standard were analyzed to determine whether interference or cross-contamination had occurred. The water used throughout the study was obtained from a Milli-Q water purification system (Millipore, Sao Paulo, Brazil) with a resistivity of $18.2 \mathrm{MOhm} \mathrm{cm}$.

The results were examined and assessed in relation to the known concentration. The reported results were corrected based on a control blank. The $\mathrm{Sr}: \mathrm{Ca}$ ratios were then calculated.

Only the right sagittal otoliths were used for this study (Los Alisos, $N=15$; Cabra Corral, $N=15$; Plata River, $N=154$; Chascomús, $N=17$; Chasicó, $N=48$ ). They were rinsed in Milli-Q water and dried. Each one was weighed on an analytical balance (error $<0.001 \mathrm{~g}$ ) and digested with $50 \%$ nitric acid on a sand bed heated to $400-450{ }^{\circ} \mathrm{C}$ for $1 \mathrm{~h}$ (Avigliano et al. 2014). Otolith $\mathrm{Sr}$ was determined by ICP-OES and Ca was determined by the titration method using EDTA (APHA 1995). The equipment, procedure, and quality control were the same as used to determine water $\mathrm{Sr}$ and $\mathrm{Ca}$.
Table 1. Mean size ( \pm standard deviation) and size range of Odontesthes bonariensis per sampling site. $N=$ sample size.

Tabla 1. Media ( \pm desviación estándar) y rango de tallas de Odontesthes bonariensis por sitio de estudio. $N=$ tamaño de muestra.

\begin{tabular}{lrcc}
\hline & $N$ & $\begin{array}{c}\text { Mean size } \\
(\mathrm{cm})\end{array}$ & $\begin{array}{c}\text { Size range } \\
(\mathrm{cm})\end{array}$ \\
\hline Los Alisos Dam & 15 & $25.9 \pm 2.1$ & $21.6-29.6$ \\
Cabra Corral Dam & 15 & $25.1 \pm 3.8$ & $21.7-31.8$ \\
Plata River estuary & 154 & $30.3 \pm 3.6$ & $23.3-35.4$ \\
Chascomús Lagoon & 17 & $22.6 \pm 2.8$ & $22.2-31.0$ \\
Chasicó Lake & 48 & $34.8 \pm 2.5$ & $26.7-41.6$ \\
\hline
\end{tabular}

\section{Determinación de Sr y Ca en agua y otolitos}

La concentración de $\mathrm{Ca}$ en el agua fue determinada por triplicado mediante el método volumétrico de titulación con ácido etilendiaminotetraacético (EDTA) (APHA 1995). La concentración de $\mathrm{Sr}$ en agua fue determinada por triplicado mediante un espectrómetro de emisión óptica con plasma de acoplamiento inductivo (ICP-OES, PerkinElmer Optima 2000 DV, Überlingen, Alemania), equipado con un nebulizador de flujo cruzado, cámara Scott y antorcha de cuarzo (método 200.7, EPA 1994). Se utilizó un eje de visión radial atenuado (límite de detección $=12 \mu \mathrm{g} \mathrm{L}^{-1}$ ). Las muestras fueron introducidas al equipo por medio de un muestreador automático Perkin-Elmer AS-90 Plus. En todos los casos se realizaron calibraciones externas utilizando el estándar Quality Control Standard 21 (QCS 21), PerkinElmer Pure (EUA). Cada 10 muestras, se analizaron un blanco y una muestra de concentración conocida preparada a partir del estándar QCS 21 para determinar si había interferencia y contaminación cruzada. El agua utilizada en todo el estudio se obtuvo de un sistema de purificación de agua Milli-Q (Millipore, São Paulo, Brasil) con una resistividad de 18.2 MOhm cm.

Los resultados fueron revisados y evaluados en relación con las muestras de concentración conocida. Los resultados registrados fueron corregidos según un blanco control. Posteriormente, se calcularon las relaciones $\mathrm{Sr}: \mathrm{Ca}$.

En este estudio se utilizó únicamente el otolito sagitta derecho (Los Alisos, $N=15$; Cabra Corral, $N=15$; Río de la Plata, $N=154$; Chascomús, $N=17$; Chasicó, $N=48$ ). Los otolitos fueron limpiados con agua Milli-Q y secados. Cada uno fue pesado con una balanza analítica (error $<0.001 \mathrm{~g}$ ) y digerido en ácido nítrico al $50 \%$ sobre un baño de arena calentado entre $400-450^{\circ} \mathrm{C}$ durante $1 \mathrm{~h}$ (Avigliano et al. 2014). La concentración de $\mathrm{Sr}$ en otolito se determinó por ICP-OES y la de Ca por el método de titulación con EDTA (APHA 1995). El equipamiento, procedimiento y control de calidad empleados en los procedimientos fueron detallados previamente para las determinaciones de $\mathrm{Sr}$ y $\mathrm{Ca}$ en agua. 
The efficiency of the otolith digestion process was verified using certified reference materials (FEBS-1, National Research Council, Canada) and an acceptable recovery percentage was obtained (93\% for $\mathrm{Sr}$ and $110 \%$ for $\mathrm{Ca}$ ). All otolith determinations were made in triplicate.

\section{Otolith morphometry}

The right sagittal otoliths of all the fish specimens captured were photographed under a stereoscopic microscope (Leica EZ4 HD). The following morphometric variables were recorded on the images using an image processor (Image-ProPlus 4.5): otolith length (OL), otolith width $(\mathrm{OW})$, and otolith perimeter (OP), in millimeters; and otolith area (OA) and sulcus area (SA), in square millimeters. The following shape indices were then calculated: circularity $\left(\mathrm{OP}^{2} / \mathrm{OW}\right)$, rectangularity $(\mathrm{OA} /[\mathrm{OL} \times \mathrm{OW}])$, ellipticity $(\mathrm{OL}-\mathrm{OW} / \mathrm{OL}+\mathrm{OW})$, form factor $\left(\left[4 \pi \times \mathrm{OA} / \mathrm{OP}^{2}\right]\right)$, and $\mathrm{SA} / \mathrm{OA}$. The nomenclature of the indices used was taken from Tuset et al. (2013) and Volpedo et al. (2008). Circularity provides information on the complexity of the otolith contour (Tuset et al. 2003). Rectangularity gives information on the approximation to a rectangular or square shape, a value of 1 indicating a perfect rectangle or square. Ellipticity reflects the similarity to an ellipse, values close to 0 indicating a tendency towards circularity. The form factor is a dimensionless value that indicates the similarity of the otolith contour to a circle; its values range from 0 to 1 , a value of 1 corresponding to a perfect circle (Tuset et al. 2003). The SA/OA index indicates the percentage of the otolith area occupied by the sulcus. The sulcus is the contact area of the otolith with the saccular macula that transmits information to the brain about the relative position of the fish in the water column and auditory information (Volpedo et al. 2008).

\section{Statistical analysis}

The Sr:Ca ratio of the water from the different sampling sites was compared by a Kruskal-Wallis nonparametric analysis of variance. The $\mathrm{Sr}: \mathrm{Ca}$ ratio in the otoliths was transformed with the function $\log (x+1)$ because the assumptions of normality and homogeneity of variance were not met (Shapiro-Wilk and Levene tests, respectively). After verifying these assumptions, an analysis of covariance (ANCOVA) was applied to determine if otolith weight affected the Sr:Ca ratio. The $\mathrm{Sr}: \mathrm{Ca}$ ratio correlated positively with otolith weight and was corrected by subtracting the common slope in ANCOVA $(P<0.01, b=0.033)$ (Longmore et al. 2010, Kerr and Campana 2014, Avigliano et al. 2015b). This fit eliminated the effect of otolith weight on the transformed $\mathrm{Sr}: \mathrm{Ca}$ variable (ANCOVA, $P>0.05$ ). Finally, the $\mathrm{Sr}$ Ca ratio in the otoliths was compared among study sites by a univariate analysis of variance (ANOVA) and Tukey's multiple comparison test. The mean water and otolith Sr:Ca ratios were represented in box plots.
La eficiencia del proceso de digestión de los otolitos fue verificada con el material de referencia FEBS-1 (Otolith Certified Reference Material, National Research Council, Canadá) y se obtuvo un porcentaje de recuperación del material de referencia aceptable (93\% para $\mathrm{Sr}$ y $110 \%$ para $\mathrm{Ca}$ ). Todas las determinaciones para los otolitos fueron realizadas por triplicado.

\section{Morfometría de los otolitos}

Los otolitos sagittae derechos de todos los ejemplares capturados fueron fotografiados con un microscopio estereoscópico (Leica EZ4 HD). Se registraron las siguientes variables morfométricas sobre las imágenes mediante el procesador de imágenes Image-ProPlus 4.5: longitud del otolito (LO), anchura del otolito (AO) y perímetro del otolito (PO), en milímetros; y área del otolito (SO) y área del sulcus (SS), en milímetros cuadrados. Posteriormente, se calcularon los siguientes índices de forma: circularidad $\left(\mathrm{PO}^{2} / \mathrm{AO}\right)$, rectangularidad $(\mathrm{SO} /[\mathrm{LO} \times \mathrm{AO}])$, elipticidad $(\mathrm{LO}-\mathrm{AO} / \mathrm{LO}+\mathrm{AO})$, factor de forma $\left(\left[4 \pi \times \mathrm{SO} / \mathrm{PO}^{2}\right]\right)$ y $\mathrm{SS} / \mathrm{SO}$. La nomenclatura de los índices utilizados fue tomada de Tuset et al. (2013) y Volpedo et al. (2008). La circularidad da información acerca de la complejidad del contorno de los otolitos (Tuset et al. 2003). La rectangularidad da información sobre la aproximación a una forma rectangular o cuadrada, siendo igual a 1 un rectángulo o cuadrado perfecto. La elipticidad refleja la similitud del otolito con una elipse, tendiendo a la circularidad con valores cercanos a 0 . El factor de forma es un valor adimensional que indica la similitud del contorno de los otolitos respecto de un círculo y sus valores están comprendidos entre $0 \mathrm{y} 1$, siendo un valor de 1 para un círculo perfecto (Tuset et al. 2003). El índice SS/SO determina qué porcentaje de la superficie del otolito está ocupado por el sulcus. El sulcus es el área de contacto entre el otolito y la mácula nerviosa que transmite al cerebro información relacionada con la posición relativa del pez en la columna de agua y con la captación auditiva (Volpedo et al. 2008).

\section{Análisis estadístico}

La relación Sr:Ca del agua fue comparada entre los sitios de muestreo mediante el análisis no paramétrico de KruskalWallis. La variable Sr:Ca de los otolitos fue transformada con la función $\log (x+1)$ debido al incumplimiento de los supuestos de normalidad y homogeneidad de la varianza (pruebas de Shapiro-Wilk y Levene, respectivamente). Después de la comprobación de estos supuestos, se utilizó el análisis de covarianza (ANCOVA) para determinar si existía un efecto del peso de los otolitos sobre la relación Sr:Ca. La relación $\mathrm{Sr}: C a$ correlacionó positivamente con el peso del otolito y fue corregida substrayendo la pendiente común del ANCOVA $(P<0.01, b=0.033)$ (Longmore et al. 2010, Kerr y Campana 2014, Avigliano et al. 2015b). Este ajuste eliminó el efecto 
The morphometric variables did not fit the normal distribution and homogeneity of variance (Shapiro-Wilk, $P<$ 0.01 ; Levene, $P>0.05$ ) and were therefore transformed with the function $\log (x+1)$. ANCOVA $(P<0.01)$ was then used to correct the effect of otolith length on the studied variables. The following constants were used for the correction: circularity, $b=-0.03$; rectangularity, $b=-0.01$; ellipticity, $b=$ -0.01 ; form factor, $b=0.17$; and SA/OA, $b=-0.003$. The morphometric variables were analyzed by ANOVA and Tukey's test was used to evaluate the differences among sampling sites. Moreover, a multivariate analysis of variance (MANOVA) was applied to determine whether differences existed among sites considering all the morphometric variables simultaneously. Hotelling's $\mathrm{T}^{2}$ test was then applied to evaluate the differences among sites.

A canonical discriminant analysis (CDA) was performed using the morphometric variables in order to obtain the crossclassification matrix and determine the capacity of these variables to identify the site of origin of the fish (e.g., Longmore et al. 2010, Kerr and Campana 2014). The standardized canonical discriminant function coefficients were used to determine the contribution of each variable to the discrimination of the groups. All statistical analyses were performed using InfoStat.

\section{RESULTS}

\section{Sr:Ca ratio in water and otoliths}

The Chasicó Lake water samples had high $\mathrm{Sr}: \mathrm{Ca}$ values (Kruskal-Wallis, $P<0.001$ ). Low values were recorded for the Plata estuary and Los Alisos Dam waters, and there were no differences between these two sites (Kruskal-Wallis, $P>0.05$ ) (fig. 2a). Intermediate values were obtained for the water samples from Cabra Corral Dam and Chascomús Lagoon $(P>0.05)$ (fig. 2a).

There were no significant differences between the $\mathrm{Sr}: \mathrm{Ca}$ ratios of the silverside otoliths from the Cabra Corral Dam and Plata estuary (ANOVA, $P<0.05$ ). Differences were found, however, between the $\mathrm{Sr}: \mathrm{Ca}$ ratios of the otoliths from the other sampling sites $(P<0.05)$. They were significantly lower in the otoliths from Los Alisos Dam and higher in those from Chasicó Lake (fig. 2b).

\section{Otolith morphometry}

A representative image of the otoliths from each site is shown in figure 3.

Significantly high circularity and ellipticity values were obtained for the Chasicó Lake otoliths (table 2), indicating high edge complexity and an elliptical morphology. The Chascomús Lagoon otoliths had significantly low rectangularity and circularity values $(P<0.05)$, whereas the form factor was significantly high $(P<0.05)$. This indicates a morphology tending towards circularity with low edge del peso de los otolitos sobre la variable $\mathrm{Sr}: \mathrm{Ca}$ transformada (ANCOVA $(P>0.05)$. Finalmente, la relación Sr:Ca del otolito fue comparada entre los sitios de estudio mediante el análisis de la varianza (ANOVA) univariado y la comparación múltiple de Tukey. Las relaciones medias de Sr:Ca del agua y otolitos fueron representadas en gráficos de cajas.

Las variables morfométricas no se ajustaron a la distribución normal y homogeneidad de la varianza (Shapiro-Wilk, $P<0.01$; Levene, $P>0.05$ ), y por este motivo fueron transformadas con la función $\log (x+1)$. Posteriormente, se utilizó el ANCOVA con el fin de corregir el efecto de la longitud del otolito sobre las variables estudiadas $(P<0.01)$. Las constantes utilizadas para la corrección fueron las siguientes: circularidad, $b=-0.03$; rectangularidad, $b=-0.01$; elipticidad, $b=$ -0.01 ; factor de forma, $b=0.17$; SS/SO, $b=-0.003$. Las variables morfométricas fueron analizadas mediante un ANOVA usando la prueba de Tukey para evaluar las diferencias entre sitios. Por otro lado, el análisis multivariado de la varianza (MANOVA) fue aplicado para evaluar la existencia de diferencias significativas entre los sitios de estudio considerando todas las variables morfométricas en simultáneo. Posteriormente, se aplicó la prueba de comparación de pares $\mathrm{T}^{2}$ de Hotelling para evaluar las diferencias entre los sitios de muestreo.

Un análisis discriminante canónico (ADC) fue realizado utilizando los índices morfométricos con el fin de obtener la matriz de clasificación cruzada y determinar la capacidad de estas variables para la identificación del sitio de origen de los peces (e.g., Longmore et al. 2010, Kerr y Campana 2014). Los coeficientes estandarizados de las funciones discriminantes canónicas fueron utilizados para determinar la contribución de cada variable en la discriminación de grupos. El programa InfoStat fue utilizado para todos los análisis estadísticos.

\section{RESUltados}

\section{Relación Sr:Ca en agua y otolitos}

Se observaron altos valores de $\mathrm{Sr}: \mathrm{Ca}$ en las muestras de agua del lago Chasicó (Kruskal-Wallis, $P<0.001$ ). Los valores fueron bajos en las muestras de agua del dique Los Alisos y el estuario del Río de la Plata, y no hubo diferencias entre estos dos sitios (Kruskal-Wallis, $P>0.05$ ) (fig. 2a). Se observaron valores intermedios en las muestras de agua del dique Cabra Corral y la laguna Chascomús $(P>0.05)$ (fig. 2a).

No se observaron diferencias significativas en la relación Sr:Ca de los otolitos de los pejerreyes provenientes de Cabra Corral y del Río de la Plata (ANOVA, $P<0.05$ ). Sin embargo, las relaciones $\mathrm{Sr}: \mathrm{Ca}$ de los otolitos del resto de las áreas de estudio difirieron entre sí $(P<0.05)$, y fueron significativamente menor en los otolitos de los pejerreyes del dique Los Alisos y mayor en los peces del lago Chasicó (fig. 2b). 

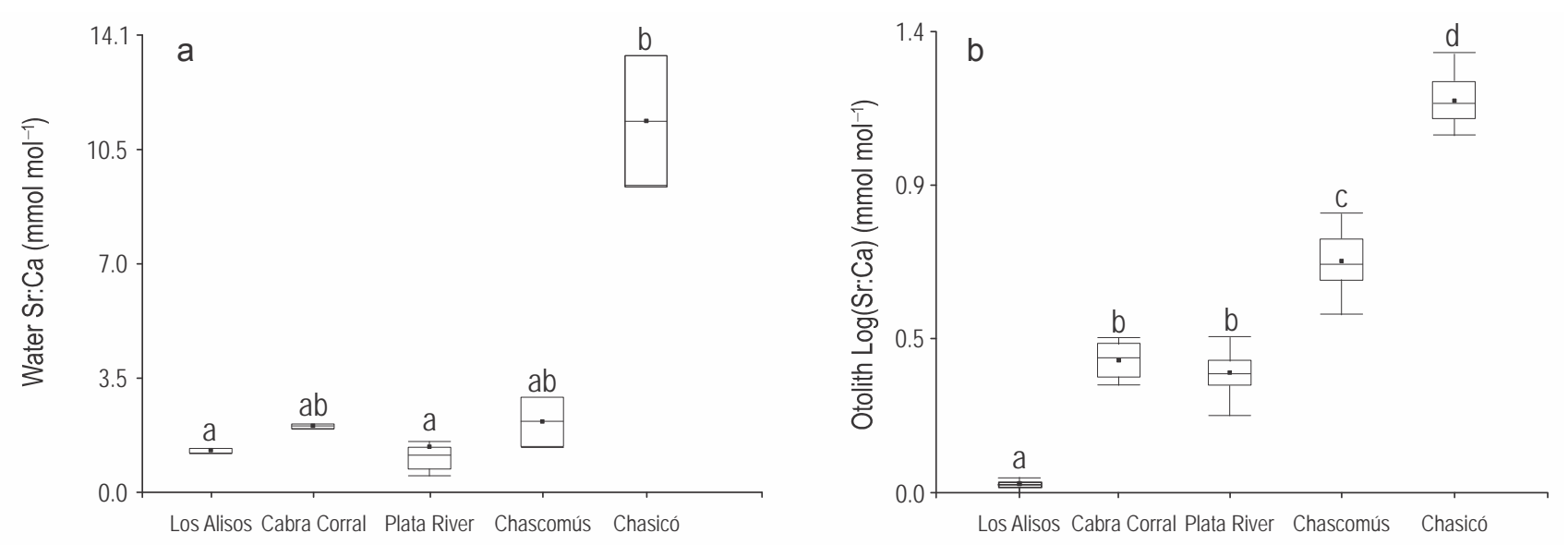

Figure 2. Mean Sr:Ca ratio of water (a) and otoliths (b) per sampling site. The bars indicate the standard deviation.

Figura 2. Relación Sr:Ca media del agua (a) y de los otolitos (b) por sitio de estudio. Las barras indican la desviación estándar.

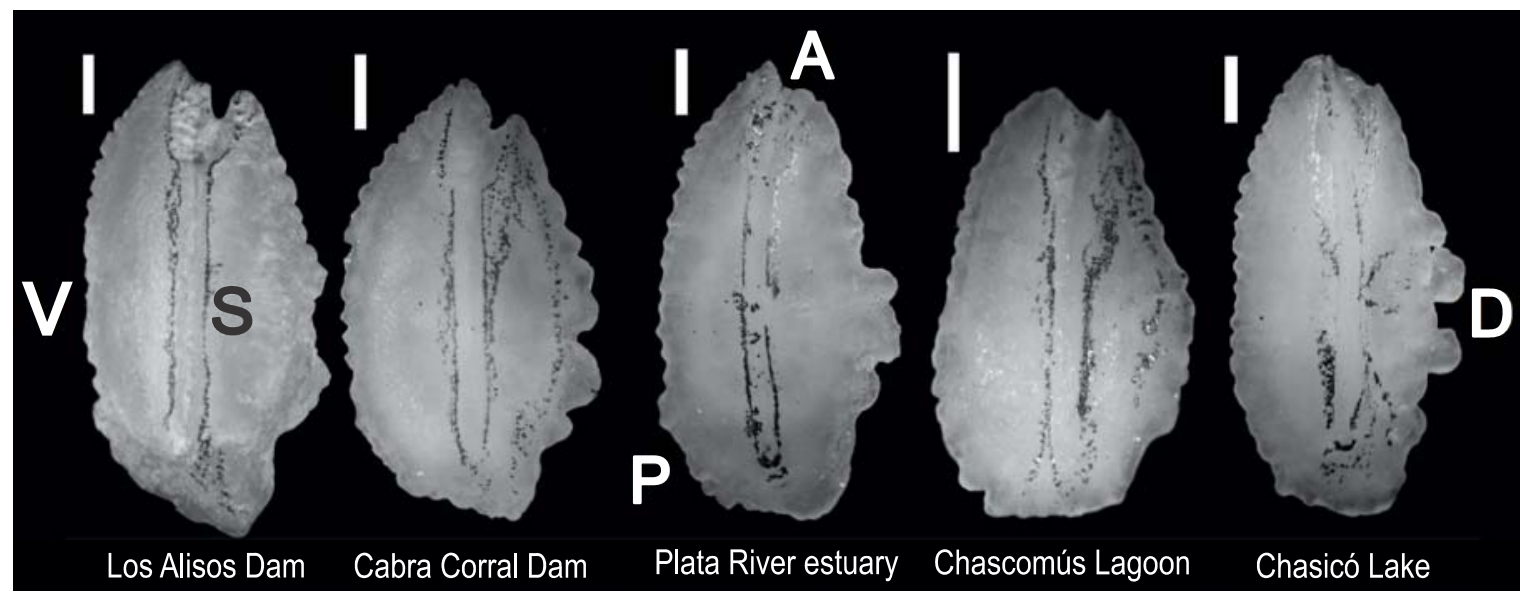

Figure 3. Right sagittal otoliths of Odontesthes bonariensis from each sampling site. The sulcus was painted with graphite under a magnifying glass $(20 \times)$ for better visualization. A, anterior; D, dorsal; S, sulcus; V, ventral; P, posterior. Bar $=1 \mathrm{~mm}$.

Figura 3. Otolitos sagitta derechos de Odontesthes bonariensis correspondientes a cada sitio de estudio. El sulcus fue pintado con grafito bajo lupa (20×) para mayor visualización. A, anterior; D, dorsal; S, sulcus; V, ventral; P, posterior. Barra $=1 \mathrm{~mm}$.

complexity. On the other hand, the SA/OA value was higher for this body of water (table 2).

The otoliths from the Plata estuary specimens tended to be elliptic-square in shape related to high ellipticity and rectangularity (table 2), and the otolith edge showed low complexity. The lowest form-factor value was recorded for the Cabra Corral otoliths, indicating a tendency towards a square shape (table 2). The otoliths from Los Alisos specimens showed high rectangularity and low edge complexity (table 2).

The MANOVA showed significant differences for the morphometric variables among the study sites $(P<0.05)$. Hotelling's $\mathrm{T}^{2}$ test did not reveal significant differences between Los Alisos and Chascomús $(P>0.05)$; however, Cabra Corral, Plata estuary, and Chasicó differed significantly among themselves and from Los Alisos and Chascomús $(P<0.001)$.

The CDA plot (fig. 4) shows a clear separation between $O$. bonariensis from Chasicó Lake and from the other four

\section{Morfometría de los otolitos}

Una imagen representativa de los otolitos de cada sitio de estudio se muestra en la figura 3.

Valores significativamente altos de circularidad y elipticidad fueron observados para los otolitos de los peces capturados en el lago Chasicó (tabla 2), resultando en otolitos con elevada complejidad de borde y morfología elíptica. Los índices de rectangularidad y circularidad fueron significativamente bajos para la laguna de Chascomús $(P<0.05)$, mientras que el factor de forma fue significativamente alto $(P<0.05)$. Esto indica una morfología tendiente a la circularidad con baja complejidad de borde. Por otro lado, la relación SS/SO fue mayor en este cuerpo de agua (tabla 2).

Los otolitos de los peces del estuario del Río de la Plata tendieron a la morfología elíptica-cuadrada relacionada con valores elevados de elipticidad y rectangularidad (tabla 2). Asimismo, el borde del otolito presentó baja complejidad. El menor valor de factor de forma se observó en los otolitos de 
Table 2. Mean \pm standard deviation of the otolith morphometric variables transformed with function $\log (x+1)$ per sampling site. Different letters in the columns indicate significant statistical differences (ANOVA, $P<0.05$ ).

Tabla 2. Media \pm desviación estándar de los índices morfométricos transformados con la función $\log (x+1)$ por sitio de estudio. Las letras diferentes indican diferencias estadísticamente significativas (ANOVA, $P<0.05$ ).

\begin{tabular}{lccccc}
\hline & Los Alisos Dam & Cabra Corral Dam & Plata River & Chascomús Lagoon & Chasicó Lake \\
\hline Circularity & $1.32 \pm 0.03^{\mathrm{a}}$ & $1.38 \pm 0.04^{\mathrm{b}}$ & $1.32 \pm 0.04^{\mathrm{a}}$ & $1.31 \pm 0.04^{\mathrm{a}}$ & $2.02 \pm 0.05^{\mathrm{c}}$ \\
Rectangularity & $0.24 \pm 0.00^{\mathrm{b}}$ & $0.23 \pm 0.01^{\mathrm{ab}}$ & $0.23 \pm 0.01^{\mathrm{b}}$ & $0.22 \pm 0.05^{\mathrm{a}}$ & $0.24 \pm 0.01^{\mathrm{b}}$ \\
Ellipticity & $0.10 \pm 0.01^{\mathrm{a}}$ & $0.10 \pm 0.01^{\mathrm{a}}$ & $0.11 \pm 0.01^{\mathrm{ab}}$ & $0.08 \pm 0.04^{\mathrm{a}}$ & $0.11 \pm 0.01^{\mathrm{b}}$ \\
Form factor & $0.22 \pm 0.01^{\mathrm{bc}}$ & $0.19 \pm 0.02^{\mathrm{a}}$ & $0.21 \pm 0.01^{\mathrm{b}}$ & $0.23 \pm 0.02^{\mathrm{c}}$ & $0.21 \pm 0.02^{\mathrm{b}}$ \\
Sulcus area/otolith area & $0.06 \pm 0.004^{\mathrm{a}}$ & $0.06 \pm 0.004^{\mathrm{a}}$ & $0.06 \pm 0.005^{\mathrm{a}}$ & $0.09 \pm 0.004^{\mathrm{b}}$ & $0.06 \pm 0.003^{\mathrm{a}}$ \\
\hline
\end{tabular}

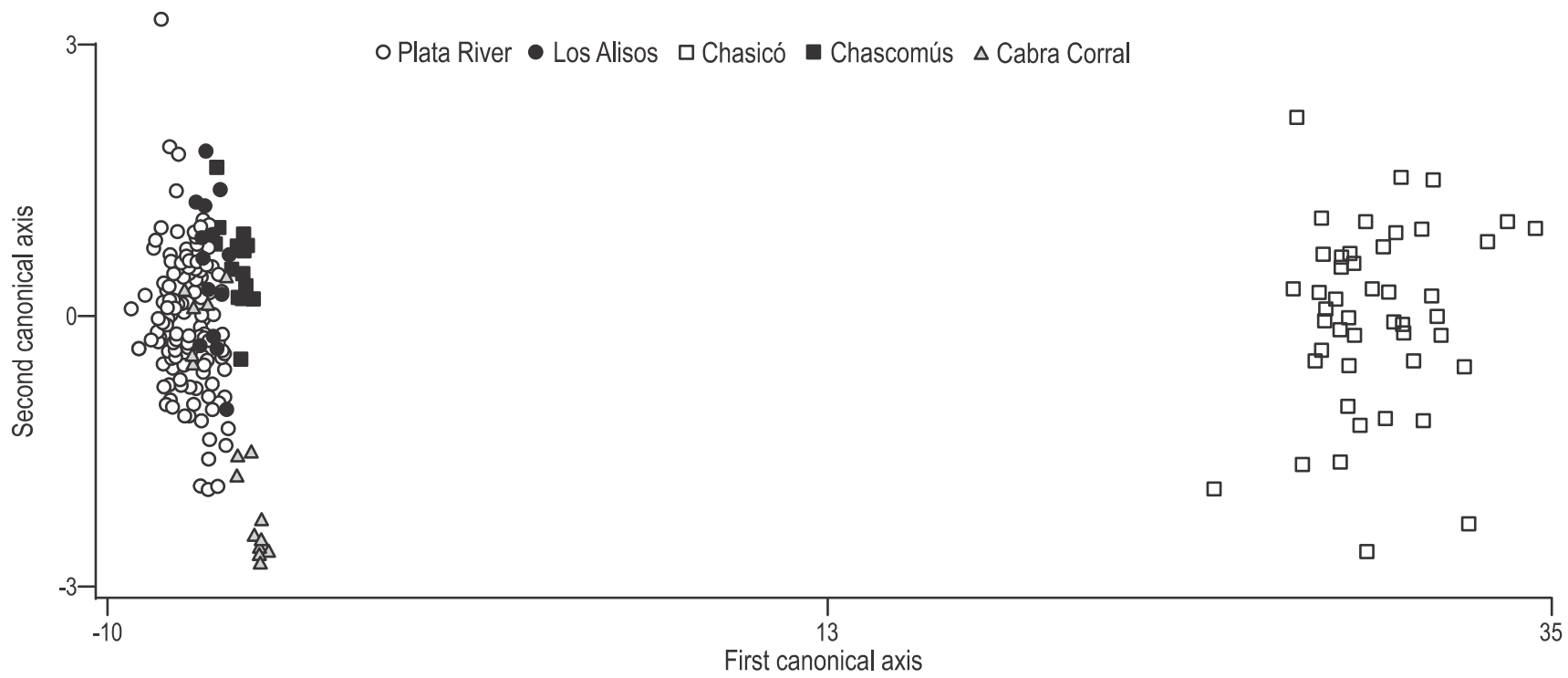

Figure 4. Canonical discriminant analysis of all the otolith morphometric variables.

Figura 4. Análisis canónico discriminante de todos los índices morfométricos de los otolitos.

sites. The data corresponding to the Chascomús Lagoon fish tended to separate from that corresponding to the Plata estuary fish. The Cabra Corral and Los Alisos values overlap. The first canonical axis explained $99.8 \%$ of the variance among groups. According to the standardized canonical discriminant function coefficients (SC) obtained, the indices that contributed most to the discrimination along this axis were circularity $(\mathrm{SC}=2.27)$ and form factor $(\mathrm{SC}=2.05)$, followed by rectangularity $(\mathrm{SC}=-0.51), \mathrm{SA} / \mathrm{OA}(\mathrm{SC}=-0.42)$, and ellipticity $(\mathrm{SC}=-0.04)$. The CDA cross-classification table (table 3) revealed a high percentage of correctly classified individuals for Chasicó Lake (100\%) and Los Alisos Dam $(80 \%)$, and a moderate percentage of correctly classified individuals for Chascomús Lagoon, Cabra Corral Dam, and Plata estuary (60-64.7\%).

\section{DISCUSSION}

The concentration of elements deposited in otoliths can to a large extent be affected by the chemical composition of the
Cabra Corral, lo que indica una tendencia a la forma cuadrada (tabla 2). El Dique Los Alisos estuvo asociado elevados índices de rectangularidad y baja complejidad de borde.

El MANOVA mostró diferencias significativas para las variables morfométricas entre los sitios de estudio $(P<0.05)$. Acorde a la prueba $\mathrm{T}^{2}$ de Hotelling, no se hallaron diferencias significativas entre Los Alisos y Chascomús $(P>0.05)$. Sin embargo, Cabra Corral, Río de la Plata y Chasicó difirieron entre si y se diferenciaron de los Alisos y Chascomús $(P<0.001)$.

El ADC (fig. 4) mostró una clara separación de los ejemplares provenientes del lago Chasicó respecto del resto de los cuerpos de agua. Por otro lado, la nube de dispersión correspondiente a los otolitos de los pejerreyes de la laguna Chascomús tendió a separarse de la del Río de la Plata. Se observó una superposición entre los valores de los otolitos de los pejerreyes provenientes de los diques de Los Alisos y Cabra Corral. El primer eje canónico explicó el 99.8\% de la variación entre grupos. Según los coeficientes estandarizados de las funciones discriminantes canónicas obtenidos (CE), 
Table 3. Cross-classification table of the canonical discriminant analysis of the otolith morphometric variables. The numbers in parentheses represent the classification percentage.

Tabla 3. Tabla de clasificación cruzada del análisis canónico discriminante de los índices morfométricos. Los números entre paréntesis representan el porcentaje de clasificación.

\begin{tabular}{|c|c|c|c|c|c|c|}
\hline & Los Alisos Dam & Cabra Corral Dam & Plata River & Chascomús Lagoon & Chasicó Lake & Total \\
\hline Los Alisos & $12(80.0)$ & $1(6.6)$ & $2(13.4)$ & 0 & 0 & 15 \\
\hline Cabra Corral & $2(13.3)$ & $9(60.0)$ & $4(26.6)$ & 0 & 0 & 15 \\
\hline Plata River & $37(24.0)$ & $17(11.0)$ & $99(64.3)$ & $1(0.6)$ & 0 & 154 \\
\hline Chascomús & $5(24.4)$ & $1(5.8)$ & 0 & $11(64.7)$ & 0 & 17 \\
\hline Chasicó & 0 & 0 & 0 & 0 & $48(100)$ & 48 \\
\hline Total & 56 & 28 & 105 & 12 & 48 & \\
\hline
\end{tabular}

water and to a lesser extent by the temperature and diet (Campana 1999, Wells et al. 2003, Ranaldi and Gagnon 2008, Brown and Severin 2009, Sturrock et al. 2012). In general, the $\mathrm{Sr}$ concentration in otoliths of freshwater, estuarine, and anadromous fish species correlates positively with the salinity (e.g., Kraus and Secor 2004, Sturrock et al. 2012); however, this relationship depends on the species and should be analyzed before being used in fish stock identification, connectivity, and migration studies. Particularly in marine species, the relationship between otolith Sr and salinity tends to be weak (Brown and Severin 2009, Sturrock et al. 2012). Brown and Severin (2009) indicated that the water Sr:Ca ratio is more homogenous in marine environments than in freshwater or brackish environments. Hence, the variation in otolith $\mathrm{Sr}$ :Ca ratios of marine species is strongly influenced by physiological factors rather than by exposure to heterogenous environments (Campana 1999, Brown and Severin 2009).

Odontesthes bonariensis, a highly plastic species, tolerates a wide range of salinities and inhabits both freshwater and saltwater environments, including rivers, lagoons, lakes, and estuaries (Brian and Dyer 2006, Avigliano and Volpedo 2013a). In this study, the water and otolith $\mathrm{Sr}: \mathrm{Ca}$ ratios showed similar tendencies. Even though the Plata River presents a wide range of conductivity, these tendencies are consistent with the salinity and conductivity reported for the studied water bodies (Muñoz et al. 2005, Llames et al. 2009, Avigliano et al. 2012, Avigliano and Volpedo 2013b). This suggests that salinity at the sampling sites is positively related to the water and otolith $\mathrm{Sr}: \mathrm{Ca}$ ratios, as has been reported by other authors for different estuarine and freshwater species in diverse aquatic systems (Brown and Severin 2009, Sturrock et al. 2012). The fact that $\mathrm{Sr}$ incorporation into otoliths is affected by the environment makes this element a potential tool for future fish displacement and stock identification studies. In this sense, the otolith Sr:Ca ratio proved to be a good marker of habitat for $O$. bonariensis. It has also been reported to be a good indicator of habitat for two other South American euryhaline species, Lycengraulis grossidens (Mai et al. 2014) and Micropogonias furnieri los índices que más contribuyeron a la discriminación sobre este eje fueron circularidad $(\mathrm{CE}=2.27) \mathrm{y}$ el factor de forma $(\mathrm{CE}=2.05)$, seguidos de rectangularidad $(\mathrm{CE}=-0.51), \mathrm{SS} /$ $\mathrm{SO}(\mathrm{CE}=-0.42)$ y elipticidad $(\mathrm{CE}=-0.04)$. La tabla de clasificación cruzada del ADC (tabla 3) mostró un alto porcentaje de individuos bien clasificados para el Lago Chasicó (100\%) y los Alisos (80\%). Por otro lado, el porcentaje de peces bien clasificados fue moderado para Chascomús, Cabra corral y el Río de la Plata (60-64.7\%).

\section{DISCUSIÓN}

La concentración de los elementos depositados en los otolitos puede ser afectada en gran medida por la composición química del agua y en menor medida por la temperatura y la dieta (Campana 1999, Wells et al. 2003, Ranaldi y Gagnon 2008, Brown y Severin 2009, Sturrock et al. 2012). En general, la concentración de $\mathrm{Sr}$ en los otolitos de especies de agua dulce, estuarinas y anádromas se correlaciona positivamente con la salinidad del agua (e.g., Kraus y Secor 2004, Sturrock et al. 2012); sin embargo, esta relación depende de la especie y debe ser evaluada previamente a la aplicación en estudios de identificación de poblaciones pesqueras, conectividad o migración. Particularmente para las especies marinas, la relación entre el Sr del otolito y la salinidad tiende a ser débil (Brown y Severin 2009, Sturrock et al. 2012). Brown y Severin (2009) indicaron que la relación Sr:Ca del agua es más homogénea en ambientes marinos que en ambientes de agua dulce o ambientes salobres. Por lo tanto, la variación del Sr:Ca en los otolitos de especies marinas está fuertemente influenciada por factores fisiológicos, más que el resultado de la exposición a entornos heterogéneos (Campana 1999, Brown y Severin 2009).

El pejerrey $O$. bonariensis es una especie altamente plástica que tolera intervalos de salinidad amplios y habita tanto en ambientes dulceacuícolas como salobres, ya sean ríos, lagunas, estuarios o albuferas (Brian y Dyer 2006, Avigliano y Volpedo 2013a). En este trabajo se encontró una tendencia similar para las relaciones Sr:Ca del agua y otolitos. Además, si bien el estuario del Río de la Plata presenta 
(Albuquerque et al. 2012). Ibáñez et al. (2012) used Sr:Ca ratios to study displacement patterns of mugilid species in the Caribbean Sea, while Hedger et al. (2008) applied this methodology to other salinity-tolerant species of the Northern Hemisphere, including Anguilla rostrata.

Other approaches such as the analysis of otolith morphology and morphometry have been widely used to differentiate fish stocks (Longmore 2010, Cañás et al. 2012, Keating et al. 2014, Vieira et al. 2014), and even to identify existing species (Tuset et al. 2013, Zhuang et al. 2014) or fossilized fish (Reichenbacher et al. 2009, Reichenbacher and Reichard 2014); however, only a few studies relate morphometric variables to different environments or ecomorphological patterns (Nelson et al. 1994; Volpedo and Fuchs 2010; Avigliano et al. 2012, 2014).

Previous studies have reported a positive relationship between salinity or conductivity and the tendency towards ellipticity of $O$. bonariensis otoliths from Chasicó Lake (Avigliano et al. 2012) and the Plata estuary (Avigliano et al. 2014); these studies used the otolith width:length index as an indicator of ellipticity. In agreement with these authors, in the present study we found that the otoliths tended to be elliptic or elliptic-square in shape in more saline systems, such as Chasico Lake and the Plata estuary, and observed relatively low ellipticity in less saline systems, such as Chascomús Lagoon and the Cabra Corral and Los Alisos dams (table 2).

The size of the sulcus has also been associated with mobility (Lombarte and Popper 1994, Arellano et al. 1995, Tuset et al. 2003, Avigliano et al. 2014). For example, in some species of the genus Merluccius, this index was associated with water column use; however, in some species of the genus Mullus, it was associated with differences in feeding behavior (Aguirre and Lombarte 1999). Avigliano et al. (2014) reported that the SA/OA ratio tends to be greater in populations of $O$. bonariensis from the Plata estuary that undertake long migrations. In the present study, the relationship between displacements and relative size of the sulcus was not evident since the SA/OA index for the Plata River, where most migratory propulations are found, was similar or significantly lower than that obtained for the lentic water bodies (table 2). This could be due to different reasons. First, the sulcus area was analyzed in a two-dimensional plane without considering sulcus depth, which may differ depending on the different environments studied and habits of the populations (see Tuset et al. 2003). Second, the presence of a less migratory population, which tends to remain for a longer time in saline waters of the Plata estuary (Avigliano et al. 2014), may have a negative effect on the SA/OA index; however, this option seems less likely because the two known stocks migrate (to a lesser or greater extent) during the breeding period and overlap considerably in the study area (Avigliano et al. 2014).

Excluding ellipticity, the indices calculated for the otoliths of $O$. bonariensis from the Plata estuary fell within the range obtained for the other study sites (table 2). This un rango amplio de conductividad, estas tendencias son consistentes con la salinidad o conductividad reportada para estos cuerpos de agua (Muñoz et al. 2005, Llames et al. 2009, Avigliano et al. 2012, Avigliano y Volpedo 2013b). Esto sugiere que la salinidad de los sitios de estudio está relacionada positivamente con la relación $\mathrm{Sr}: \mathrm{Ca}$ del agua y del otolito, tal como indicaron otros autores para diferentes especies estuarinas y dulceacuícolas en diversos sistemas acuáticos (Brown y Severin 2009, Sturrock et al. 2012). El hecho de que la incorporación de $\mathrm{Sr}$ en otolitos sea afectada por el medio ambiente hace de este elemento una herramienta potencial para futuros estudios sobre los desplazamientos de peces y la identificación de poblaciones pesqueros. En este sentido, la relación Sr:Ca del otolito resultó ser buen marcador de hábitat para el pejerrey. Otros autores reportaron que la relación $\mathrm{Sr}: \mathrm{Ca}$ del otolito es un buen indicador de hábitat para algunas especies eurihalinas de Sudamérica, como la sardina Lycengraulis grossidens (Mai et al. 2014) y la corvina Micropogonias furnieri (Albuquerque et al. 2012). Ibáñez et al. (2012) utilizaron la relación Sr:Ca para el estudio de patrones de desplazamiento de diferentes especies de mugílidos del mar Caribe, mientras que Hedger et al. (2008) aplicaron esta metodología para otras especies del hemisferio norte con gran tolerancia a la salinidad, como Anguilla rostrata.

Otras metodologías como la morfología y morfometría del otolito han sido ampliamente utilizadas para la diferenciación de poblaciones pesqueras (Longmore 2010, Cañás et al. 2012, Keating et al. 2014, Vieira et al. 2014), e incluso para identificar especies actuales (Tuset et al. 2013, Zhuang et al. 2014) o fosilizadas (Reichenbacher et al. 2009, Reichenbacher y Reichard 2014). Sin embargo, los estudios que relacionan las variables morfométricas con diferentes ambientes o patrones ecomorfologicos son escasos (Nelson et al. 1994; Volpedo y Fuchs 2010; Avigliano et al. 2012, 2014).

Estudios previos han reportado una relación positiva entre la salinidad o conductividad y la tendencia a la elipticidad en otolitos de O. bonariensis del lago Chasicó (Avigliano et al. 2012) y del estuario del Río de la Plata (Avigliano et al. 2014). En estos estudios se utilizó el índice anchura:longitud del otolito como indicador de elipticidad. Acorde con estos autores, en nuestra investigación se observó una morfología del otolito elíptica o elíptica-cuadrada en los sistemas de mayor salinidad como el lago Chasicó y el estuario del Río de la Plata. Los sistemas con menor salinidad, como la laguna de Chascomús y los diques Los Alisos y Cabra Corral, presentaron elipticidad relativamente baja (tabla 2).

Diferentes autores relacionan el tamaño del sulcus con la movilidad (Lombarte y Popper 1994, Arellano et al. 1995, Tuset et al. 2003, Avigliano et al. 2014). Por ejemplo, en algunas especies del genero Merluccius, este índice estaría relacionado con el uso de la columna de agua; sin embargo, en algunas especies del género Mullus estaría asociado a diferencias en el comportamiento de alimentación (Aguirre 
could be attributed to the migratory behavior of the species in the estuary, since one of the stocks distributed in Samborombón Bay during summer (November-May), migrates for the purpose of breeding to the large rivers of the Paraná Delta (freshwater) during the cold months of the year (June-October) (Avigliano and Volpedo 2013b). Hence, the estuarine fish are exposed to different habitats and important changes in temperature and salinity, which would be reflected in the otolith morphometry.

The differences found using multiparametric tests indicate a high dissimilarity in otolith shapes, particularly in the circularity, form factor, and rectangularity indices. The CDA classification percentages are similar to those reported by other authors (see for example Tuset et al. 2003), who have indicated that the otolith shape indices can be used as natural markers, not only to separate the species, but also to identify populations. The morphometric variables analyzed herein should therefore be useful indicators of habitat.

In summary, our findings indicate that the Sr:Ca ratio and otolith morphometry are good markers of habitat for the silverside $O$. bonariensis. The data reported here serve as reference for studies on the biology and population dynamics (life history, stock identification, etc.) of this and other euryhaline species. The studied variables can be used to identify stocks in other South American basins where the species is found (e.g., Plata Basin, Lagoa dos Patos) and evaluate the degree of connectivity among them. This information is important for the proper management of fishery resources.

\section{ACKNOWLEDGMENTS}

Funding was received from the Consejo Nacional de Investigaciones Científicas y Técnicas (CONICET, Argentina, PIP 112-20120100543CO), Agencia Nacional de Promoción Científica y Tecnológica (ANPCyT, Argentina, PIP 2010-1372), and University of Buenos Aires (UBACYT 20620110100007). We thank the editor and reviewers for their valuable comments.

English translation by Christine Harris.

\section{REFERENCES}

Aguirre H, Lombarte A. 1999. Ecomorphological comparisons of sagittae in Mullus barbatus and M. surmuletus. J. Fish Biol. 55: $105-114$.

Albuquerque CQ, Miekeley N, Muelbert JH, Walther BD, Jaureguizar AJ. 2012. Estuarine dependency in a marine fish evaluated with otolith chemistry. Mar. Biol. 159: 2229-2239.

[APHA] American Public Health Association. 1995. Standard Methods for the Examination of Water and Wastewater. 19th ed. APHA, Washington, DC. 541 pp.

Arellano RV, Hamerlynck O, Vinex M, Mees J, Hostens K, Gijselinck W. 1995. Changes in the ratio of the sulcus acusticus area to the sagitta area of Pomatoschistus minutus and P. lozanoi (Pisces, Gobiidae). Mar. Biol. 122: 355-360. y Lombarte 1999). Avigliano et al. (2014) han reportado que SS/SO tiende a ser mayor en las poblaciones de $O$. bonariensis que realizan grandes migraciones en el estuario del Río de la Plata. En este trabajo la relaciones entre los desplazamientos y el tamaño relativo del sulcus no fue evidente ya que el índice SS/SO par el Río de la Plata, donde se hallan las poblaciones migrantes, fue similar o significativamente inferior al obtenido para los cuerpos de agua lénticos (tabla 2). Esto podría deberse a diferentes motivos. En primer lugar, en este trabajo se consideraron únicamente variables en dos dimensiones, y es posible que la profundidad del sulcus muestre diferencias dependiendo de los diferentes ambientes estudiados y hábitos de las poblaciones (ver Tuset et al. 2003). En segundo lugar, la presencia de una población con una menor característica migratoria, que tiende a permanecer más tiempo en aguas salobres del estuario del Río de la Plata (Avigliano et al. 2014), podría tener un efecto negativo en el índice $\mathrm{SS} / \mathrm{SO}$; sin embargo esta última opción es poco factible debido a que las dos poblaciones conocidas migran (en menor o mayor medida) en el período reproductivo y se superponen considerablemente en la zona de muestreo (Avigliano et al. 2014).

Excluyendo la elipticidad, los índices calculados para los otolitos de los pejerreyes del estuario del Río de la Plata estuvieron dentro del intervalo obtenido para el resto de los sitios de estudio (tabla 2). Esto podría deberse al comportamiento migratorio de la especie en el estuario, ya que una de las poblaciones que se distribuye en aguas salobres de la bahía Samborombón durante el verano (noviembre-mayo) se desplaza con fines reproductivos hacia los grandes ríos del delta del Paraná (agua dulce) en los meses fríos del año (junio-octubre) (Avigliano y Volpedo 2013b). En este sentido, los peces del estuario estarían sometidos a importantes cambios de hábitats con gran variabilidad tanto en temperatura como en salinidad, lo cual se reflejaría en la morfometría de los otolitos.

Las diferencias halladas con las pruebas multiparamétricas sugieren la existencia de alta disimilaridad en la morfología de los otolitos, particularmente en los índices de circularidad, factor de forma y rectangularidad. Los porcentajes de clasificación del ADC fueron similares a los obtenidos por otros autores (ver por ejemplo Tuset et al. 2003) que indicaron que los índices de forma de los otolitos pueden ser utilizados como marcadores naturales, no sólo para separar especies sino también para identificar poblaciones. En este sentido, las variables morfométricas estudiadas en este trabajo serían útiles como marcadores del hábitat.

En conclusión, los resultados de este trabajo indican que la relación Sr:Ca y la morfometría del otolito son buenos indicadores de hábitat para el pejerrey $O$. bonariensis. La información aquí presentada es un punto de referencia para el estudio de la biología y dinámica poblacional (historia de vida, identificación de poblaciones pesqueras, etc.) de especies eurihalinas, en especial $O$. bonariensis. En este sentido, las variables estudiadas pueden ser utilizadas en diferentes 
Avigliano E. 2014. Otolith and its application to determine commercial fish stocks from de la Plata River and the South Atlantic coast. PhD thesis, Universidad de Buenos Aires, Argentina. $127 \mathrm{pp}$.

Avigliano E, Volpedo AV. 2013a. Actinopterygii, Atheriniformes, Atherinopsidae, Odontesthes bonariensis Valenciennes 1835: New records for the Plata Basin, Argentina. Check List 9: 640-641.

Avigliano E, Volpedo AV. 2013b. Use of otolith strontium:calcium ratio as indicator of seasonal displacements of the silverside (Odontesthes bonariensis) in a freshwater-marine environment. Mar. Freshwat. Res. 64(8):746-751

Avigliano E, Tombari A, Volpedo AV. 2012. ¿Los otolitos reflejan el estrés ambiental? Biol. Acuat. 27: 9-5.

Avigliano E, Riaños Martinez CF, Volpedo AV. 2014. Combined use of otolith microchemistry and morphometry as indicators of the habitat of the silverside (Odontesthes bonariensis) in a freshwater-estuarine environment. Fish. Res. 149: 55-60.

Avigliano E, Saez MB, Rico R, Volpedo AV. 2015a. Use of otolith strontium:calcium and zinc:calcium ratios as an indicator of the habitat of Percophis brasiliensis Quoy \& Gaimard, 1825 in the southwestern Atlantic Ocean. Neotrop. Ichthyol. http://dx.doi.org/10.1590/1982-0224-20130235

Avigliano E, Velasco G, Volpedo AV. 2015b. Use of lapillus otolith microchemistry as an indicator of the habitat of Genidens barbus from different estuarine environments in the southwestern Atlantic Ocean. Environ. Biol. Fish. http://dx.doi.org/10.1007/s10641-015-0387-3

Avigliano E, Velasco G, Volpedo AV. 2015c. Assessing the use of two southwestern Atlantic estuaries by different life cycle stages of the anadromous catfish Genidens bar bus (Lacépéde 1803) as revealed by $\mathrm{Sr}: \mathrm{Ca}$ and $\mathrm{Ba}: \mathrm{Ca}$ ratios in otoliths. J. Appl. Ichthyol. http://dx.doi.org/10.1111/jai.12766

Barco V. 1986. Análisis de la situación actual y perspectivas de desarrollo pesquero en embalses de Colombia. Trabajos presentados al Taller internacional sobre ecología y manejo de peces en lagos y embalses. Santiago, Chile, 5-10 de noviembre de 1984. COPESCAL Documento Técnico (FAO), (4): 237pp.

Brian S, Dyer H. 2006. Systematic revision of the South American silversides (Teleostei, Atheriniformes). Biocell 30: 69-88.

Brown RJ, Severin KP. 2009. Otolith chemistry analyses indicate that water $\mathrm{Sr}: \mathrm{Ca}$ is the primary factor influencing otolith $\mathrm{Sr}: \mathrm{Ca}$ for freshwater and diadromous fish but not for marine fish. Can. J. Fish. Aquat. Sci. 66: 1790-1808.

Campana SE. 1999. Chemistry and composition of fish otoliths: Pathways, mechanisms and applications. Mar. Ecol. Prog. Ser. 188: 263-297.

Cañás L, Stransky C, Schlickeisen J, Sampedro MP, Fariña AC. 2012. Use of the otolith shape analysis in stock identification of anglerfish (Lophius piscatorius) in the Northeast Atlantic. ICES J. Mar. Sci. 69: 250-256. http://dx.doi.org/10.1093/icesjms/fss006

Chiba K, Taki Y, Sakai K, Oozeki Y. 1989. Present status of aquatic organisms introduced into Japan. In: De Silva SS (ed.), Exotic Aquatic Organisms in Asia. Proceedings of the Workshop on Introduction of Exotic Aquatic Organisms in Asia. Spec. Publ. Asian Fish. Soc., pp. 63-70.

[EPA] Environmental Protection Agency. 1994. Methods for the Determination of Metals in Environmental Samples. Supplement 1. EPA.Cincinnati, Ohio, 58 pp.

Escalante A, Grosman F. 2001. Alimentación natural del pejerrey. In: Grosman F (ed.), Fundamentos Biológicos, Económicos y Sociales para una Correcta Gestión del Recurso Pejerrey. Editorial Astyanax, Azul, Buenos Aires, pp. 67-75. cuencas de Sudamérica donde la especie se encuentra distribuida (e.g., cuenca del Plata, sistema de Lagoa dos Patos) para identificar diferentes poblaciones pesqueras y evaluar el grado de conexión entre las mismos. Esta información es de vital importancia para gestión y manejo de los recursos pesqueros.

\section{Agradecimientos}

Los autores agradecen el financiamiento por parte del Consejo Nacional de Investigaciones Científicas y Técnicas (CONICET, Argentina, PIP 112-20120100543CO), la Agencia Nacional de Promoción Científica y Tecnológica (ANPCyT, Argentina, PIP 2010-1372) y la Universidad de Buenos Aires (UBACYT 20620110100007). Agradecemos al editor y a los revisores por los detallados comentarios que ayudaron a mejorar la calidad del manuscrito.

Gandolfi G, Zerunian S, Torricelli P, Marconato AI. 1991. Pesci delle acque interne italiane. Ministero dell'Ambiente e Unione Zoologica Italiana. Instituto Poligrafico e Zecca dello Stato, Roma. 618 pp.

Guerrero RA, Piola AR, Molinari G, Osiroff AP. 2010. Climatología de temperatura y salinidad en el Río de la Plata y su Frente Marítimo, Argentina-Uruguay. 1st ed. Mar del Plata, Argentina. Instituto Nacional de Investigación y Desarrollo Pesquero. $95 \mathrm{pp}$.

Hedger RD, Atkinson PM, Thibault I, Dodson JJ. 2008. A quantitative approach for classifying fish otolith strontium: calcium sequences into environmental histories. Ecol. Inform. 3: 207-217.

Ibáñez AL, Chang CW, Hsu CC, Wang CH, lizuka Y, Tzeng WN. 2012. Diversity of migratory environmental history of the mullets Mugil cephalus and M. curema in Mexican coastal waters as indicated by otolith $\mathrm{Sr}: \mathrm{Ca}$ ratios. Cienc. Mar. 38: 73-87.

Keating JP, Brophy D, Officer RA, Mullins E. 2014. Otolith shape analysis of blue whiting suggests a complex stock structure at their spawning grounds in the Northeast Atlantic. Fish. Res. 157: $1-6$.

Kerr LA, Campana SE. 2014. Chemical composition of fish hard parts as a natural marker of fish stocks. In: Cadrin SX, Kerr LA, Mariani S (eds.), Stock Identification Methods: Applications in Fishery Science. Academic Press, pp. 205-234.

Kraus RT, Secor ER. 2004. Incorporation of strontium into otoliths of an estuarine fish. J. Exp. Mar. Biol. Ecol. 302: 85-106.

Lestrel PE. 1997. Fourier Descriptors and their Applications in Biology. Cambridge University Press, Cambridge, UK, 466 pp.

Llames ME, Lagomarsino L, Diovisalvi N, Fermani P, Torremorell AM, Perez G, Unrein F, Bustingorry J, Escaray R, Ferraro M, Zagarese HE. 2009. The effects of light availability in shallow, turbid waters: A mesocosm study. J. Plankton Res. 31: $1517-1529$. http://dx.doi.org/10.1093/plankt/fbp086

Lombarte A, Popper AN. 1994. Quantitative analysis of postembryonic hair cell addition in the otolithic endorgans of the inner ear of the European hake, Merluccius merluccius (Gadiformes, Teleostei). J. Comp. Neurol. 345: 419-428. 
Longmore C, Fogarty K, Neat F, Brophy D, Trueman C, Milton A, Mariani S. 2010. A comparison of otolith microchemistry and otolith shape analysis for the study of spatial variation in a deepsea teleost, Coryphaenoides rupestris. Environ. Biol. Fish. 89: 591-605.

Mai AC, Condini MV, Albuquerque CQ, Loebmann D, Saint'Pierre TD, Miekeley N, Vieira JP. 2014. High plasticity in habitat use of Lycengraulis grossidens (Clupeiformes, Engraulididae). Estuar. Coast. Shelf. Sci. 141: 17-25.

[MINAGRI] Ministerio de Agricultura, Ganadería y Pesca de la Nación. 2014. Estadísticas: Productos de río por origen y destino. Argentina [cited 15 August 2014]. Available from: http://www.minagri.gob.ar/site/pesca/index.php.

Muñoz LM, Barros SE, Chihan SE, Franqui FR, Barrientos DJ. 2005. Rendimiento de la pesca deportiva del pejerrey (Odontesthes bonariensis) en el embalse Cabra corral, Salta, Noroeste de Argentina. In: Memorias del VI Congreso Internacional sobre Manejo de Fauna Silvestre en la Amazonia y Latinoamérica, Iquitos, Perú, pp. 86-91.

Nelson K, Hutchinson ES, Li G, Sly FL, Hedgecock D. 1994. Variation in life history and morphology in northern anchovies (Engraulis mordax). CalCOFI Rep. 35: 108-120.

Park L, Moran P. 1994. Developments in molecular genetic techniques in fisheries. Rev. Fish Biol. Fish. 4: 272-299.

Ranaldi MM, Gagnon MM. 2008. Zinc incorporation in the otoliths of juvenile pink snapper (Pagrus auratus Forster): The influence of dietary versus waterborne sources. J. Exp. Mar. Biol. Ecol. 360: 56-62.

Reichenbacher B, Reichard M. 2014. Otoliths of five extant species of the annual killifish Nothobranchius from the East African savannah. PloS ONE 9: e112459.

Reichenbacher B, Kamrani E, Esmaeili HR, Teimori A. 2009. The endangered cyprinodont Aphanius ginaonis (Holly, 1929) from southern Iran is a valid species: Evidence from otolith morphology. Environ. Biol. Fish. 86: 507-521.

Schuchert PC, Alexander I, Arkhipkin E, Koenig AE. 2010. Traveling around Cape Horn: Otolith chemistry reveals a mixed stock of Patagonian hoki with separate Atlantic and Pacific spawning grounds. Fish. Res. 102: 80-86.

Secor DH, Henderson-Arzapalob A, Piccoli PM. 1995. Can otolith microchemistry chart patterns of migration and habitat utilization in anadromous fishes? J. Exp. Mar. Biol. Ecol. 192: 15-33.

Sturrock AM, Trueman CM, Darnaude AM, Hunter E. 2012. Can otolith elemental chemistry retrospectively track migrations in fully marine fishes? J. Fish Biol. 81: 766-795. http://dx.doi.org/10.1111/j.1095-8649.2012.03372.x

Tabouret H, Bareille G, Clverie F, Pecheyran C, Prouzet P, Donard OF. 2010. Simultaneous use of strontium:calcium and barium:calcium ratios in otoliths as markers of habitat: Application to the European eel (Anguilla anguilla) in Adour Basin, South West France. Mar. Environ. Res.70: 35-45.

Tombari A, Volpedo VA. 2008. Modificaciones en la distribución original de especies por impacto antrópico: El caso de Odontesthes bonariensis (Pisces: Atherinopsidae). In: Volpedo AV, Fernández Reyes L (eds.), Efecto de los Cambios Globales sobre la Biodiversidad. Buenos Aires, Argentina, pp. 155-165.

Tuset VM, Lombarte A, Gonzalez JA, Pertusa JF, Lorente MJ. 2003. Comparative morphology of the sagittal otolith in Serranus spp. J. Fish Biol. 63: 1491-1504.

Tuset VM, Parisi-Baradad V, Lombarte A. 2013. Application of otolith mass and shape for discriminating scabbardfishes Aphanopus spp. in the north-eastern Atlantic Ocean. J. Fish. Biol. 82: 1746-1752.

Vervoorst FB. 1967. Las comunidades vegetales de la Depresión del Salado. La Vegetación de la República Argentina, Serie Fitogeográica No. 7, Buenos Aires INTA, 259 pp.

Vieira AR, Neves A, Sequeira V, Paiva RB, Gordo LS. 2014. Otolith shape analysis as a tool for stock discrimination of forkbeard (Phycis phycis) in the Northeast Atlantic. Hydrobiologia 728: 103-110.

Volpedo AV, Fuchs DV. 2010. Ecomorphological patterns of the lapilli of Paranoplatense Siluriforms (South America). Fish. Res. 102(1): 160-165.

Volpedo AV, Tombari AD, Echeverría DD. 2008. Eco-morphological patterns of the sagitta of Antarctic fish. Polar Biol. 31: 635-640.

Wells BK, Rieman BE, Clayton JL, Horan DL, Jones CM. 2003. Relationships between water, otoliths, and scale chemistries of Westslope cutthroat trout from the Coeur d'Alene River, Idaho: The potential application of hard-part chemistry to describe movements in freshwater. Trans. Am. Fish. Soc. 132: 409-424.

Zhuang L, Ye Z, Zhang C. 2014. Application of otolith shape analysis to species separation in Sebastes spp. from the Bohai Sea and the Yellow Sea, northwest Pacific. Environ. Biol. Fish. 98: 547-558. http://dx.doi.org/10.1007/s10641-014-0286-Z

Zlokovitz ER, Secor DH, Piccoli PM. 2003. Patterns of migration in Hudson River striped bass as determined by otolith microchemistry. Fish. Res. 63: 245-259.

Received September 2014, accepted January 2015. 